\title{
Community structure and diversity of bryophytes and vascular plants in abandoned fen meadows
}

\author{
Markus Peintinger ${ }^{1,3, *}$ and Ariel Bergamini ${ }^{2}$ \\ ${ }^{1}$ Institute of Environmental Sciences, University of Zürich, Winterthurerstr. 190, CH-8057, Zürich, \\ Switzerland; ${ }^{2}$ Swiss Federal Institute for Forest, Snow and Landscape Research WSL, Zürcherstrasse 111, \\ CH-8903, Birmensdorf, Switzerland; ${ }^{3}$ Güttinger Str. 8/1, D-78315, Radolfzell, Germany; *Author for \\ correspondence (e-mail: peinti@t-online.de; phone: +49-7732-919527; fax: +49-7732-919528)
}

Received 19 July 2005; accepted in revised form 8 November 2005

Key words: Aboveground biomass, Caricion davallianae, Litter, Mowing, Secondary succession, Species density, Switzerland

\begin{abstract}
We examined effects of abandonment on species diversity and species composition by comparing 21 calcareous fen meadows in the pre-alpine zone of central and northeastern Switzerland. Meadows were divided into three classes of successional stages (mown: annually mown in late summer, young fallow: 4-15 years, and old fallow: >15 years of abandonment). In each fen, we measured litter mass in four $20 \mathrm{~cm} \times 20 \mathrm{~cm}$ plots, as well as (aboveground) biomass and species density (number of species per unit area) of bryophytes and vascular plants. Bryophyte biomass was reduced in abandoned fens, whereas litter mass and aboveground biomass of vascular plants increased. Species density of both taxonomic groups was lower in abandoned than in mown fens. Young and old successional stages were not different except for bryophytes, for which old successional stages had higher species density than young stages. We used litter mass and aboveground biomass of vascular plants as covariables in analyses of variance to reveal their effects on species density of both taxonomic groups. For bryophytes, litter mass was more important than vascular plant biomass in explaining variance of species density. This indicates severe effects of burying by litter on bryophyte species density. For species density of vascular plants, both vascular plant biomass and litter mass were of similar importance in explaining the decreased species density. Canonical correspondence analyses showed that abandonment also had an effect on species composition of both bryophytes and vascular plants. However, young and old successional stages were not different indicating fast initial changes after abandonment, but slow secondary succession afterwards. Furthermore, indicator species analysis showed that there was no establishment of new species after abandonment that might dramatically alter fen communities. Re-introduction of mowing as a nature conservation strategy may thus be very promising - even for old fallows.
\end{abstract}

\section{Introduction}

In central Europe, many species-rich grassland communities are maintained either by extensive grazing or mowing (Ellenberg 1996). Due to rationalization of farming practices, many for- merly traditionally managed grasslands are nowadays either used more intensively or management has ceased completely. The cessation of management leads to secondary succession which is a serious problem in nature conservation. Abandonment often results in (1) the replacement of 
specialist by generalist species; (2) the decrease of species diversity; and (3) the establishment of woody or invasive species (Zoller and Bischof 1980; Schiefer 1981; Bosshard et al. 1988; Maas 1988; Buchwald 1996; Jensen and Schrautzer 1999; Billeter and Diemer 2000; Diemer et al. 2001). The accumulation of litter is one of the most important mechanisms changing species composition after abandonment. A thick litter layer reduces radiation at the soil surface, shades out small and shortlived species, and inhibits germination and establishment of seedlings (Facelli and Pickett 1991; Xiong and Nilsson 1999).

Effects of abandonment are well documented for vascular plants, but only few studies have focussed on bryophytes. The two taxonomic groups differ substantially in respect to their physiology, anatomy, and morphology. Most bryophytes are ectohydric (Buch 1947) and have neither roots nor an efficient internal vascular system. Water and nutrient uptake occur over the whole plant surface. Consequently, bryophytes are restricted in size and, therefore, interactions with vascular plants for light are extremely asymmetric (Rydin 1997, 'amensalistic' following Økland 2000). Although many bryophytes are shade-tolerant because of low light compensation points (Proctor 1981) studies demonstrate that light can be an important factor influencing growth and plasticity of bryophytes (Bates 1988; Rincon and Grime 1989; Bergamini and Peintinger 2002). Furthermore, bryophyte biomass and diversity decrease with increasing vascular plant biomass, at least in temperate grasslands (Bergamini and Pauli 2001; Bergamini et al. 2001a; Hájková and Hájek 2003).

In abandoned grasslands the accumulation of litter may strongly affect light availability of the bryophyte layer thereby limiting growth of the bryophytes. However, only few studies have examined the effect of litter on the bryophyte layer (Wheeler and Giller 1982; van Tooren et al. 1988; Hájková and Hájek 2003) and they lead to different results. Besides negative effects of litter, there may also be positive ones. For example, decomposing litter might enhance growth of bryophytes by nutrient release (Rincon 1988; Frego and Carleton 1995).

In general, there are only few studies which examine both taxonomic groups with the same intensity (e.g., Ingerpuu et al. 2001). In this study, we explored the effects of abandonment on both bryophytes and vascular plants. We are not aware of another study examining simultaneously the effect of abandonment on both bryophytes and vascular plants. In a previous study, Diemer et al. (2001) have examined the effect of abandonment in the same region but their study has been restricted to vascular plants and has been focussed on environmental factors (soil nitrogen, soil nitrate, and $\mathrm{pH}$ ) and structural features of the canopy. We asked whether abandonment affects (aboveground) biomass, species density (species number per unit area), and species composition of both bryophytes and vascular plants. Furthermore, we examined to what extent litter mass and aboveground biomass of vascular plants explained variance in species density and species composition.

\section{Materials and methods}

\section{Study area}

We studied 21 calcareous fen meadows in the prealpine zone of central and north-eastern Switzerland. The dominating plant community belongs to the Caricion davallianae alliance according to the Braun-Blanquet system (Ellenberg 1996) which are species-rich in both bryophytes and vascular plants (Bergamini et al. 2001b; Peintinger et al. 2003). Productivity measured as aboveground biomass of vascular plants is rather low (Pauli et al. 2002) and bryophyte biomass can sometimes exceed aboveground biomass of vascular plants (Bergamini et al. 2001a).

In each of six regions we selected one to four abandoned fens as well as one annually mown litter meadow (Table 1, Diemer et al. 2001). Fens with Caricion davallianae vegetation were randomly selected out of the national fen inventory (BUWAL 1990). To estimate age since abandonment local farmers were asked and these statements were verified by counting growth rings of established woody species.

Age since abandonment varied between 4 and 35 years. Because the estimation of time since abandonment was only roughly estimated we built classes of successional stages (mown: annually mown in late summer, young: $4-15$ years, and old: $>15$ years of abandonment). Using this classification, we got three almost equally sized groups and, thus, only a slightly unbalanced design for the 
Table 1. Location and characteristics of the study sites (calcareous fens).

\begin{tabular}{|c|c|c|c|c|c|c|c|}
\hline Region & Canton & Site & Management status & Fallow age (year) & Successional stage & Altitude (m a.s.l.) & Soil $\mathrm{pH}$ \\
\hline \multirow[t]{5}{*}{ Iberg } & \multirow[t]{5}{*}{$\mathrm{SZ}$} & Chappelried 4 & Mown & 0 & 1 & 1250 & 6.3 \\
\hline & & Chappelried 2 & Abandoned & 7 & 2 & 1260 & 5.9 \\
\hline & & Chappelried 3 & Abandoned & 30 & 3 & 1240 & 6.0 \\
\hline & & Bueffen 1 & Abandoned & 10 & 2 & 1240 & 7.1 \\
\hline & & Bueffen 2 & Abandoned & 4 & 2 & 1200 & 6.4 \\
\hline \multirow[t]{4}{*}{ Alpthal } & \multirow[t]{4}{*}{$\mathrm{SZ}$} & Rund Blätz 2 & Mown & 0 & 1 & 1200 & 6.1 \\
\hline & & Seiler/Zwäcken & Abandoned & 15 & 2 & 1320 & 6.7 \\
\hline & & Rund Blätz 1 & Abandoned & 25 & 3 & 1270 & 5.8 \\
\hline & & Langried & Abandoned & 30 & 3 & 1280 & 5.5 \\
\hline \multirow[t]{3}{*}{ Wäggital } & \multirow[t]{3}{*}{$\mathrm{SZ}$} & Gnossenweid & Mown & 0 & 1 & 960 & 5.5 \\
\hline & & Bergliboden & Abandoned & 9 & 2 & 1050 & 6.6 \\
\hline & & Hirzegg & Abandoned & 35 & 3 & 1250 & 6.4 \\
\hline \multirow[t]{2}{*}{ St. Johann } & \multirow[t]{2}{*}{ SG } & Altschenchopf 1 & Mown & 0 & 1 & 1300 & 6.6 \\
\hline & & Altschenchopf 2 & Abandoned & 25 & 3 & 1280 & 7.4 \\
\hline \multirow[t]{3}{*}{ Toggenburg } & \multirow[t]{3}{*}{ SG } & Chellen & Mown & 0 & 1 & 1100 & 5.7 \\
\hline & & Rossweid & Abandoned & 20 & 3 & 1100 & 6.8 \\
\hline & & Salomonstempel & Abandoned & 20 & 3 & 1020 & 6.8 \\
\hline \multirow[t]{4}{*}{ Gais } & \multirow[t]{4}{*}{$\mathrm{AR}$} & Foren 4 & Mown & 0 & 1 & 970 & 5.7 \\
\hline & & Foren 1 & Abandoned & 12 & 2 & 1030 & 5.8 \\
\hline & & Foren 2 & Abandoned & 10 & 2 & 1040 & 5.4 \\
\hline & & Foren 3 & Abandoned & 33 & 3 & 1050 & 5.8 \\
\hline
\end{tabular}

Abbreviations for cantons: SZ: Schwyz; SG: St. Gallen; AR: Appenzell-Ausserrhoden. Successional stages: 1: Mown fens; 2: Young; and 3: Old stages. Soil pH: Average of four rewetted soil samples.

analyses. Out of the 21 study sites 6 were mown. Seven fens belonged to the young and eight to the old successional stage. The fens were situated between approx. 1000 and $1300 \mathrm{~m}$. a.s.l. (Table 1). Annual precipitation was high and varied between 1500 and $2500 \mathrm{~mm}$ (Uttinger 1967).

Soil $\mathrm{pH}$ was measured in four rewetted soil samples per site (data provided by K. Oetiker, see Diemer et al. 2001) and varied between pH 5.4 and 7.4. ANOVA with regions as blocking factor showed that $\mathrm{pH}$ varied marginally significantly among regions $\left(F_{5,13}=2.63, p=0.07\right)$, but not between successional stages $\left(F_{2,13}=2.06, p=0.17\right)$.

\section{Field study}

In July and August 2000 (i.e. at peak vascular plant biomass) four plots were randomly arranged in each fen. We used $20 \mathrm{~cm} \times 20 \mathrm{~cm}$ plots $\left(0.04 \mathrm{~m}^{2}\right)$ to assess biomass and species density of both groups. Although sample size seems rather small for assessing species density of vascular plants we used the same scale for both taxonomic groups because sampling errors are scale-dependent (Klimeš et al. 2001). Previous studies in fen meadows have shown that this plot size is suffi- cient to detect significant differences in species density (Bergamini et al. 2001a).

We first recorded all vascular plants before clipping them just above the bryophyte layer. After that, litter and bryophytes were removed completely. For the bryophytes a provisional species list was prepared in the field. Small and critical bryophytes species were sampled separately and determined in the laboratory. Some species are treated collectively because most samples of these species were too small or too poorly developed to allow for an exact determination (see Appendix, Table A.1). In the laboratory, litter, bryophytes, and the aboveground biomass were separated and their dry mass was measured after drying at $80^{\circ} \mathrm{C}$ until mass constancy. Nomenclature of vascular plants follows Lauber and Wagner (1996), and of bryophytes Geissler et al. (1998) with the exception of Drepanocladus cossonii (Schimp.) Loeske and Cratoneuron falcatum (Brid.) G. Roth which were now both accepted as distinct species.

\section{Statistical analysis}

To assess the relationships between litter mass, biomass of bryophytes, and aboveground biomass 
of vascular plants a Pearson correlation matrix was used. To examine the effects of region, successional stage and variation among sites on litter mass, biomass and species density we used nested ANOVA models. Region and successional stage were tested against the site term and differences among sites were tested against the residual error term (variation among plots). The total variation among the factor 'successional stage' was divided into two orthogonal contrasts (Rosenthal and Rosnow 1985), the first between mown and abandoned fens, and the second between the young and old successional stage. This allows to test whether mown and abandoned fens were different (contrast 1) and, further, whether young and old fallows were different (contrast 2).

To assess whether the effects of successional stage on species density can mainly be explained by the accumulation of litter mass and vascular plant biomass, the ANOVA models described above were used, but litter mass and vascular plant biomass were fitted first (and tested against the residual error term, right panel in Table 4). When using two covariables, their effects depend on the fitting sequence. Therefore, we calculated the ANOVA twice, but varied the fitting sequence of the two covariables to evaluate their relative importance. The variance explained by the ANOVAs were calculated as adjusted $R^{2}$ (Payne et al. 1993), expressed as percentage: $R_{\text {adj. }}^{2}=100[1-$ (residual mean squares/total mean squares)]. ANOVA tables were calculated using GENSTAT 5.3 (Payne et al. 1993) with the regression approach (McCullagh and Nelder 1983).

We employed canonical correspondence analysis (CCA, ter Braak 1986) to test influences of environmental variables on species composition of both vascular plants and bryophytes. As original species scores we used frequency data (number of occupied plots per site, ranging from 0 to 4). All CCAs were performed with the program CANOCO 4.0 (ter Braak and Smilauer 1998) using the default options. We used the six regions as covariables by converting them into six nominal variables. Separate CCAs were run for each environmental variable to evaluate their independent explanatory power ( $\%$ of variance explained). Afterwards, the forward selection procedure of CANOCO was applied to build a minimal model of variables explaining the species distribution data. Statistical significance of variables and ordination axes were tested by Monte Carlo permutation tests. When starting the forward selection, the following environmental variables were available: abandonment (mown or abandoned coded as 0 or 1 ), successional stage (mown, young, and old coded as 1, 2, and 3, respectively), time since abandonment (zero for mown fens), $\mathrm{pH}$, altitude, slope, litter mass, biomass of vascular plants and bryophytes. For the last three variables and for $\mathrm{pH}$, means of four plots per site were used. The forward selection was stopped when the additional effect of the last variable selected was not significant $(5 \%$ level, sequential Bonferroni correction).

We applied the indicator value method developed by Dufrêne and Legendre (1997) to identify indicator species for the three successional stages. The indicator value (IndVal) of a species was calculated as the product of its group specificity $\left(A_{i j}\right)$ with its group fidelity $\left(B_{i j}\right)$ as $\operatorname{IndVal}_{i j}=A_{i j} \times$ $B_{i j} \times 100 . A_{i j}$ was calculated by dividing the mean number of occupied plots of species $i$ across sites in group $j$ by the sum of the mean numbers of occupied plots of species $i$ over all groups, while $B_{i j}$ was calculated by dividing the number of sites in group $j$ where species $i$ is present by the total number of sites in group $j$. IndVal reaches its maximum value $(=100 \%)$ when all plots occupied by a species are found in the same group and when all plots in that group are occupied by that species. Following Dufrêne and Legendre (1997), statistical significance of the resulting IndVal was evaluated for each species by a random re-allocation procedure (1000 permutations) of sites among the three groups. Indicator value analyses were carried out with PC-ORD 3.0 (McCune and Mefford 1997).

\section{Results}

\section{Litter and biomass}

The correlation matrix (Table 2) showed a highly significant positive correlation between litter mass and aboveground biomass of vascular plants (for reasons of simplicity hereafter called vascular plant biomass). Bryophyte biomass was negatively correlated with both litter mass and vascular plant biomass. 
Table 2. Pearson correlation coefficients for litter mass, biomass of bryophytes, and aboveground biomass of vascular plants (all correlations are significant at $p<0.01$ ).

\begin{tabular}{|c|c|c|c|}
\hline & $\begin{array}{l}\text { Litter } \\
\text { mass }\end{array}$ & $\begin{array}{l}\text { Biomass } \\
\text { bryophytes }\end{array}$ & $\begin{array}{l}\text { Biomass } \\
\text { vasc. plants }\end{array}$ \\
\hline Litter mass & 1.000 & & \\
\hline $\begin{array}{l}\text { Biomass } \\
\text { bryophytes }\end{array}$ & -0.308 & 1.000 & \\
\hline $\begin{array}{l}\text { Biomass } \\
\text { vascular } \\
\text { plants }\end{array}$ & 0.439 & -0.411 & 1.000 \\
\hline
\end{tabular}

Litter mass per plot ranged from 42.5 to $470.0 \mathrm{~g} \mathrm{~m}^{-2}$. It varied among successional stages $(p<0.001)$ and was more than two-fold higher in abandoned than in mown fens $(p<0.001$, Figure 1 , Table 3), but there was no difference between the young and the old successional stage. Maximum bryophyte biomass found was $337.5 \mathrm{~g} \mathrm{~m}^{-2}$ and in only one of the 84 plots we recorded no bryophytes. Successional stage had only a marginally significant effect on bryophyte biomass $(p=0.09)$, but the contrast between mown and abandoned fens was significant $(p<0.05$, Figure 1 , Table 3$)$. Bryophyte biomass was twofold lower in abandoned than in mown fens. The aboveground biomass of vascular plants varied between 12.5 and $607.5 \mathrm{~g} \mathrm{~m}^{-2}$ and was higher in abandoned than in mown fens $(p<0.05$, Figure 1, Table 3). Again, there was no difference between the young and the old successional stage. Litter mass and vascular plant biomass showed no spatial variation (no significant region and site effects), but bryophyte biomass varied among sites $(p<0.05)$.

\section{Species density}

In total, we recorded 49 bryophyte species (including 10 liverworts) and 111 vascular plant species. Species density of bryophytes varied between 0 and 12 species per plot and that of vascular plants between 5 and 20 species. Species density of bryophytes and vascular plants were weakly, but significantly correlated (Pearson's $r=0.41, p<0.01)$.

Species density of bryophytes varied among successional stages and between mown and abandoned fens (both $p<0.01$, Table 4). It was smaller in abandoned than in mown fens (Figure 1), but higher in the old than in the young successional stage $(p<0.05)$. Furthermore, species density of bryophytes varied among sites $(p<0.05)$. It decreased with increasing litter mass $(p<0.001)$ and vascular plant biomass $(p<0.05$, Table 4 , Figure 2). When litter mass was fitted first, the effect of vascular plant biomass disappeared. However, when vascular plant biomass was fitted first, the effect of litter mass remained significant at $p<0.001$. This indicates that litter mass was the main covariable influencing species density of bryophytes. The effect of successional stage became less pronounced $(p<0.05)$ when both covariables were fitted and the contrast between mown and abandoned fens was now only marginally significant $(p<0.08)$. However, the effect of the second contrast (young vs. old) was not affected by fitting the covariables. This was expected to some extent, since neither litter mass nor vascular plant biomass significantly varied between young and old successional stages (Table 3 ).

Species density of vascular plants varied among successional stages $(p<0.01)$ and was lower in abandoned than in mown fens $(p<0.001$, Table 4 , Figure 1), but there was no difference between the young and old successional stage. Similarly to the bryophytes, it decreased with litter mass and vascular plant biomass $(p<0.001$ for both) but the fitting sequence did not change significance of the covariables (Figure 2, Table 4). This indicates, that litter mass and vascular plant biomass had additive effects on species density of vascular plants despite the significant correlation between these two variables.

\section{Species composition}

Separate CCAs for each environmental variable revealed only the nominal variable abandonment as significant in explaining the species composition of bryophytes. Bryophyte biomass, age since abandonment and successional stage were marginal significant (Table 5). For vascular plants abandonment and litter mass each explained a significant amount of variation. Marginal significant effects were again found for bryophyte biomass and age since abandonment (Table 5). However, after adding the best variable (abandonment) to each of the models the effect of all other variables was far from significance $(p>0.1)$. 

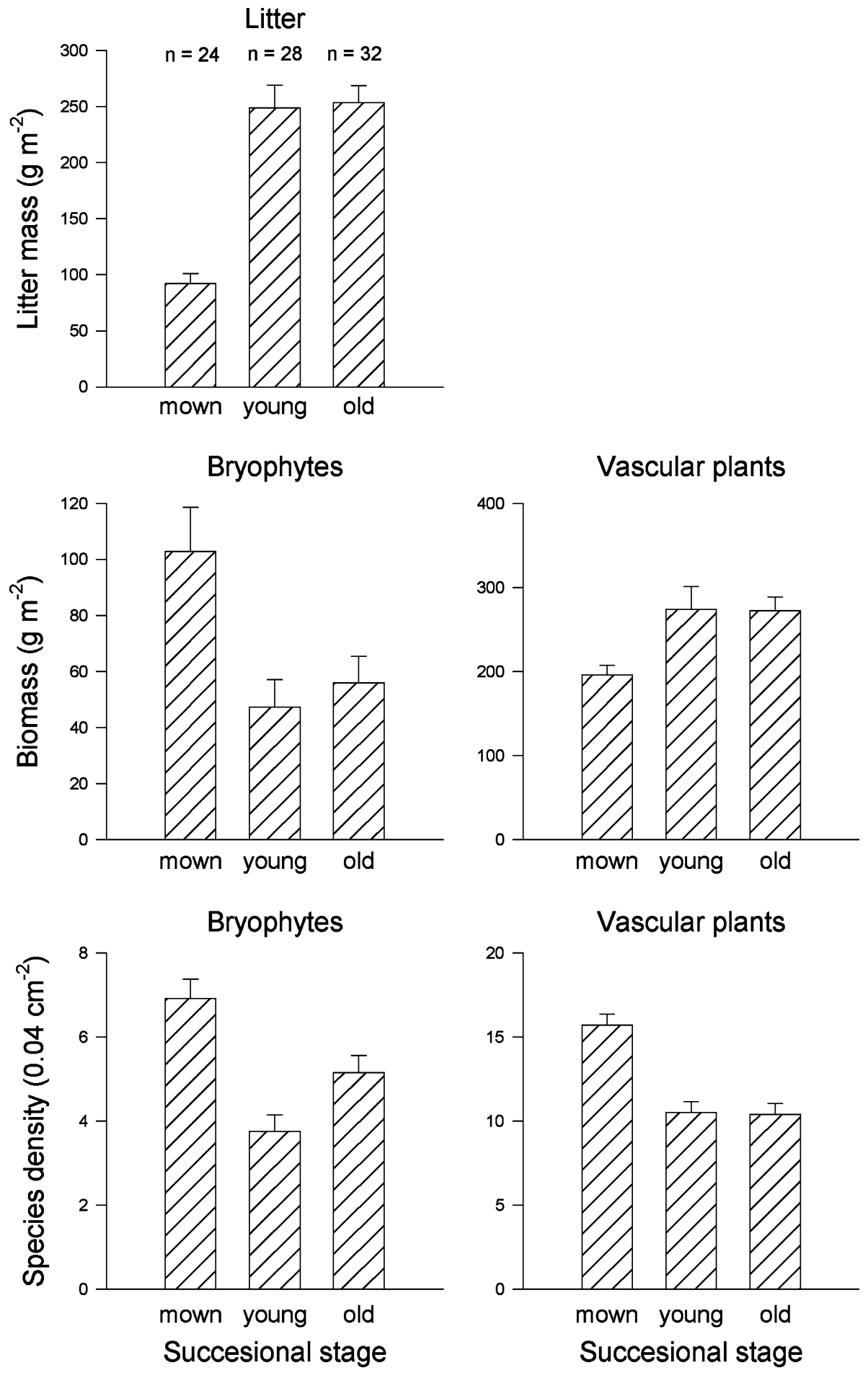

Figure 1. Effects of successional stage on litter, (aboveground) biomass, and species density of bryophytes and vascular plants (arithmetic means and standard errors are given). 
Table 3. ANOVA for the effects of region, successional stage and site on litter mass, biomass of bryophytes, and aboveground biomass of vascular plants.

\begin{tabular}{|c|c|c|c|c|c|c|c|c|c|c|}
\hline \multirow{2}{*}{$\begin{array}{l}\text { Dependent variable } \\
\text { Source of variation }\end{array}$} & \multirow[b]{2}{*}{ df } & \multicolumn{3}{|c|}{ Litter mass } & \multicolumn{3}{|c|}{$\begin{array}{l}\text { Biomass of } \\
\text { bryophytes }\end{array}$} & \multicolumn{3}{|c|}{$\begin{array}{l}\text { Aboveground biomass of } \\
\text { vascular plants }\end{array}$} \\
\hline & & SS & $F$ & Sign. & SS & $F$ & Sign. & SS & $F$ & Sign. \\
\hline Region & 5 & 111.592 & 2.30 & & 69.608 & 1.37 & & 170.96 & 1.94 & \\
\hline Successional stage & 2 & 713.330 & 24.05 & $* * *$ & 58.365 & 2.87 & & 147.76 & 4.20 & $*$ \\
\hline $\begin{array}{l}\text { Contrast 1: Mown vs. } \\
\text { Abandonment }\end{array}$ & 1 & 712.513 & 48.04 & $* * *$ & 56.919 & 5.60 & $*$ & 140.26 & 7.98 & $*$ \\
\hline $\begin{array}{l}\text { Contrast 2: Young vs. } \\
\text { Old }\end{array}$ & 1 & 0.817 & 0.06 & & 1.447 & 0.14 & & 7.50 & 0.42 & \\
\hline Site & 13 & 192.804 & 1.53 & & 132.061 & 2.17 & $*$ & 228.57 & 1.07 & \\
\hline $\begin{array}{l}\text { Residual variation } \\
\text { among plots }\end{array}$ & 63 & $\begin{array}{l}612 \cdot 117 \\
\text { adj. } R^{2}=\end{array}$ & & & $\begin{array}{l}294.572 \\
\text { adj. } R^{2}=\end{array}$ & & & $\begin{array}{l}1038.96 \\
\text { adj. } R^{2}=\end{array}$ & & \\
\hline
\end{tabular}

Variance of the factor 'successional stage' was divided into two contrasts (abandoned vs. mowing; young vs. old successional stage). adj. $R^{2}$ : adjusted percentage variance accounted for (Payne et al. 1993); df: degree of freedom; SS: sum of squares; $F$ : variance ratio; Sign.: significance: $* p<0.05 ; * * * p<0.001$.

Table 4. ANOVA with two covariables (the two possible fitting sequences are shown) for the effects of region, successional stage and site on species density of bryophytes and vascular plants.

\begin{tabular}{|c|c|c|c|c|c|c|c|c|}
\hline Source of variation & df & SS & $F$ & Sign. & $\mathrm{df}$ & SS & $F$ & Sign. \\
\hline \multicolumn{9}{|l|}{ Species density of bryophytes } \\
\hline \multicolumn{9}{|c|}{ Covariables (two possible fitting sequences $\mathrm{A}$ and $\mathrm{B}$ ) } \\
\hline (A) Litter mass & - & - & - & & 1 & 62.624 & 16.36 & $* * *$ \\
\hline Aboveground biomass of vascular plants & - & - & - & & 1 & 0.502 & 0.13 & \\
\hline (B) Aboveground biomass of vascular plants & - & - & - & & 1 & 16.904 & 4.41 & $*$ \\
\hline Litter mass & - & - & - & & 1 & 46.222 & 12.07 & $* * *$ \\
\hline Region & 5 & 37.544 & 0.85 & & 5 & 41.039 & 0.98 & \\
\hline Successional stage & 2 & 140.724 & 8.01 & $* *$ & 2 & 80.442 & 4.81 & $*$ \\
\hline Contrast 1: Mown vs. Abandoned & 1 & 91.055 & 10.37 & $* *$ & 1 & 30.013 & 3.59 & \\
\hline Contrast 2: Young vs. Old & 1 & 49.669 & 5.66 & $*$ & 1 & 50.429 & 6.02 & $*$ \\
\hline Site & 13 & 114.185 & 2.36 & $*$ & 13 & 108.796 & 2.19 & $*$ \\
\hline Residual variation among plots & 63 & \multicolumn{3}{|c|}{ adj. $R^{2}=41.4$} & 61 & \multicolumn{3}{|c|}{ adj. $\mathrm{R}^{2}=39.7$} \\
\hline \multicolumn{9}{|c|}{ Species density of vascular plants } \\
\hline \multicolumn{9}{|c|}{ Covariables (two possible fitting sequences $\mathrm{A}$ and $\mathrm{B}$ ): } \\
\hline (A) Litter mass & - & - & - & & 1 & 554.757 & 70.98 & $* * *$ \\
\hline Aboveground biomass of vascular plants & - & - & - & & 1 & 71.818 & 9.36 & $* *$ \\
\hline (B) Aboveground biomass of vascular plants & - & - & - & & 1 & 319.084 & 41.58 & $* * *$ \\
\hline Litter mass & - & - & - & & 1 & 297.491 & 38.76 & $* * *$ \\
\hline Region & 5 & 146.026 & 1.69 & & 5 & 78.969 & 1.07 & \\
\hline Successional stage & 2 & 481.159 & 13.92 & $* *$ & 2 & 83.992 & 2.84 & \\
\hline Contrast 1: Mown vs. Abandoned & 1 & 479.452 & 27.75 & $* * *$ & 1 & 81.378 & 5.51 & $*$ \\
\hline Contrast 2: Young vs. Old & 1 & 1.707 & 0.10 & & 1 & 2.614 & 0.17 & \\
\hline Site & 13 & 224.625 & 1.85 & & 13 & 192.108 & 1.93 & $*$ \\
\hline Residual variation among plots & 63 & \multicolumn{3}{|c|}{ adj. $R^{2}=46.2$} & 61 & \multicolumn{2}{|c|}{ adj. $R^{2}=55.8$} & \\
\hline
\end{tabular}

Variance of the factor 'successional stage' was divided into two contrasts (abandoned vs. mowing; young vs. old successional stages). adj. $R^{2}$ : adjusted $R^{2}$, percentage variance accounted for (Payne et al. 1993); df: degree of freedom; SS: sum of squares; $F$ : variance ratio; Sign.: significance: $* p<0.05 ; * * p 0.01 ; * * * p<0.001$. 

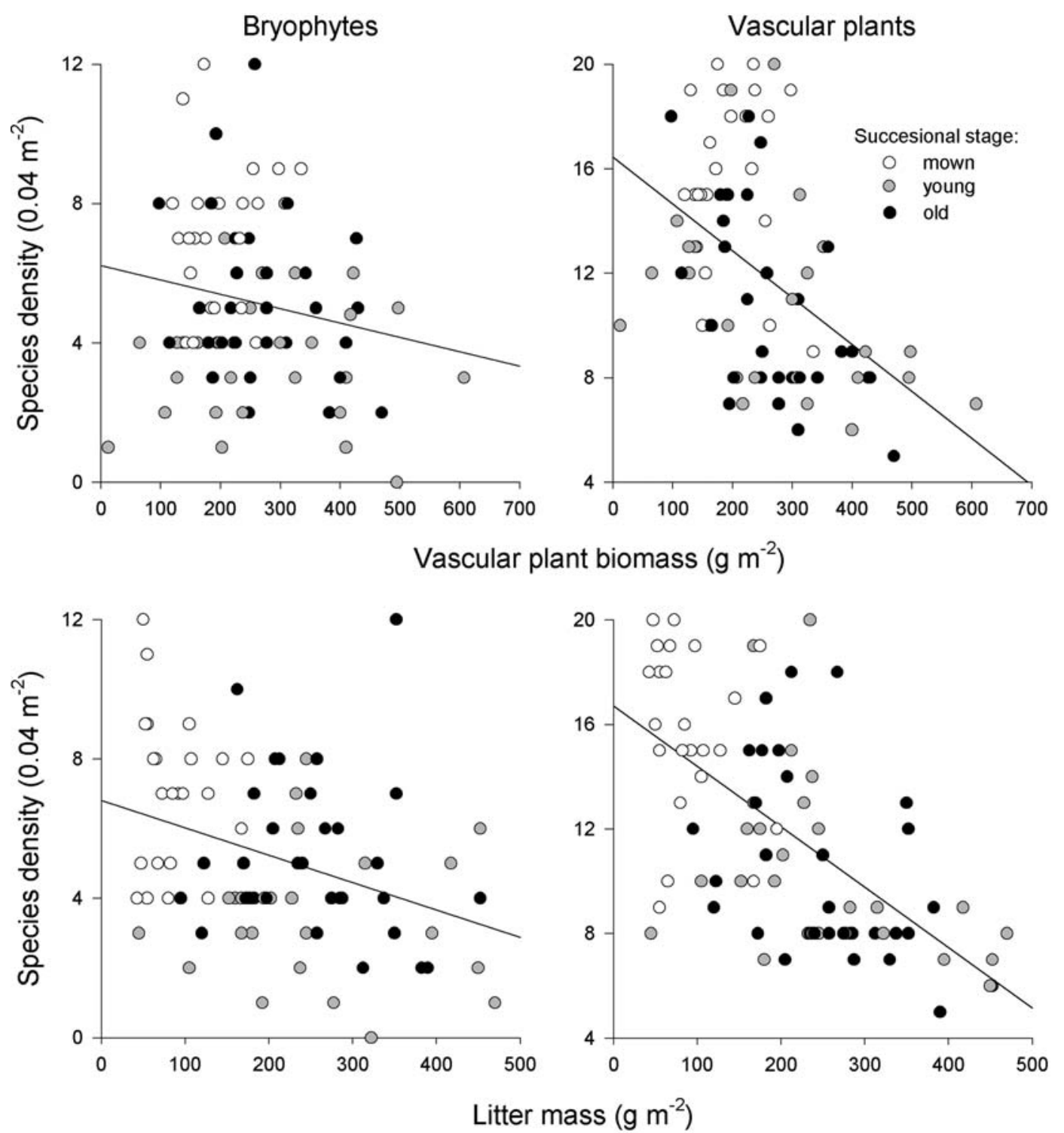

Figure 2. Relationships between biomass, species density, and litter for bryophytes and vascular plants. For vascular plants biomass refers to peak aboveground biomass. Regression lines were all significant for at least $p<0.05$ (see Tables 3 and 4 ).

The minimal model for bryophytes and vascular plants was thus the same for both and consisted only of the nominal variable abandonment. Because only one environmental variable was included in the minimal model only one canonical axis could be extracted.

Ordination diagnostics and distribution of sites in ordination space for both bryophytes and vascular plants were very similar (Table 6, Figure 3). The separation of mown and abandoned sites on the first CCA axis was conspicuous. However, young and old fallows were hardly separated along the first or the second ordination axis (Figure 3).

For bryophytes we found only 2 out of 48 (4\%) species with significant indicator values, namely Climacium dendroides and Hypnum lindbergii, which both had their highest values in mown fens (IndVal $=69 \%$ and $50 \%$, resp.). The occurrence of Hypnum lindbergii was restricted to mown fens.

For vascular plants the indicator value analysis revealed significant patterns for 11 out of $111(9 \%)$ species. Nine out of these 11 species were indica- 
Table 5. Eigenvalues and \% of variance accounted for by the first axis of separate CCAs for each environmental variable and both vascular plant and bryophyte species composition.

\begin{tabular}{|c|c|c|c|c|c|c|}
\hline & \multicolumn{3}{|l|}{ Bryophytes } & \multicolumn{3}{|c|}{ Vascular plants } \\
\hline & Eigenvalues & $\%$ variance & Sign. & Eigenvalues & $\%$ variance & Sign. \\
\hline Abandonment & 0.221 & 10.31 & $*$ & 0.196 & 9.93 & $*$ \\
\hline Litter mass & 0.195 & 9.10 & & 0.190 & 9.63 & $*$ \\
\hline Biomass bryophytes & 0.219 & 10.22 & + & 0.180 & 9.12 & + \\
\hline Age & 0.201 & 9.38 & + & 0.178 & 9.02 & + \\
\hline Altitude & 0.182 & 8.49 & & 0.177 & 8.97 & \\
\hline Successional stage & 0.206 & 9.61 & + & 0.169 & 8.56 & \\
\hline Aboveground biomass vascular plants & 0.189 & 8.82 & & 0.157 & 7.95 & \\
\hline Slope & 0.173 & 8.07 & & 0.136 & 6.89 & \\
\hline $\mathrm{pH}$ & 0.167 & 7.79 & & 0.130 & 6.59 & \\
\hline
\end{tabular}

In every CCA the six regions were used as covariables. Significance: $+p<0.1 ;{ }^{*} p<0.05$.

Table 6. Summary of CCAs for bryophytes and vascular plants, respectively, with the six regions as covariables and the only significant environmental variable 'abandonment' as explanatory variable for both bryophytes and vascular plants.

\begin{tabular}{lcc}
\hline & Bryophytes & Vascular plants \\
\hline Total inertia & 2.987 & 2.726 \\
$\begin{array}{l}\text { Inertia after fitting } \\
\text { the covariables }\end{array}$ & 2.143 & 1.974 \\
$\begin{array}{l}\text { Eigenvalue of first axis } \\
\text { \% variance accounted }\end{array}$ & 0.221 & 0.196 \\
$\quad$ for by the first axis & 10.3 & 9.9 \\
Significance of first axis & $p=0.054$ & $p=0.027$ \\
\hline
\end{tabular}

Inertia is a measure of the total amount of variance in the species composition (ter Braak and Smilauer 1998).

tive for mown fens: Carex panicea $($ IndVal $=49 \%)$, Ranunculus montanus agg. $(60 \%)$, Carex pulicaris (53\%), Juncus alpinus (56\%), Linum catharticum (52\%), Plantago lanceolata (61\%), Trifolium pratense (93\%), Polygala amarella (67\%), and Euphrasia rostkoviana $(50 \%)$. One species was found as an indicator for young fallows (Lysimachia nemorum, 43\%) and one for old fallows (Aster bellidiastrum, $56 \%$ ).

\section{Discussion}

Our study demonstrates that the cessation of management influences biomass, species density, and species composition of both bryophytes and vascular plants. Both taxonomic groups showed similar patterns with respect to species density and species composition. However, response of biomass to abandonment differed considerably between the two groups. Sampling units in our study were rather small, at least to estimate species density of vascular plants. Therefore, the abundance of rare species was rather underestimated. Still, we found clear and significant patterns in species density.

\section{Biomass and litter}

The cessation of management caused an increase of vascular plant biomass and litter. In our study, litter mass in abandoned fens was more than twice as high as in mown fens while Diemer et al. (2001) have found a 15 -fold increase of litter mass. This discrepancy can be explained by different sampling procedures. We have removed the whole moss layer and, therefore, included litter intermingled in the moss layer. In contrast, Diemer et al. (2001) have merely sampled the litter above the moss layer and, therefore, found much lower values than we found in mown meadows. However, in both studies the accumulation of litter mass was independent of the fallow age. Obviously, other variables such as nutrient supply, local climate or hydrological conditions might be more important than fallow age.

We, as well as Diemer et al. (2001), have found an increase in aboveground biomass of vascular plants in abandoned fens. This increase is congruent with other studies in fen meadows (Bosshard et al. 1988; Güsewell et al. 1998) and other grassland types (Stöcklin and Gisi 1989; Ryser et al. 1995). It is usually attributed to a process called auteutrophication which leads to a higher productivity in abandoned relative to mown fens 

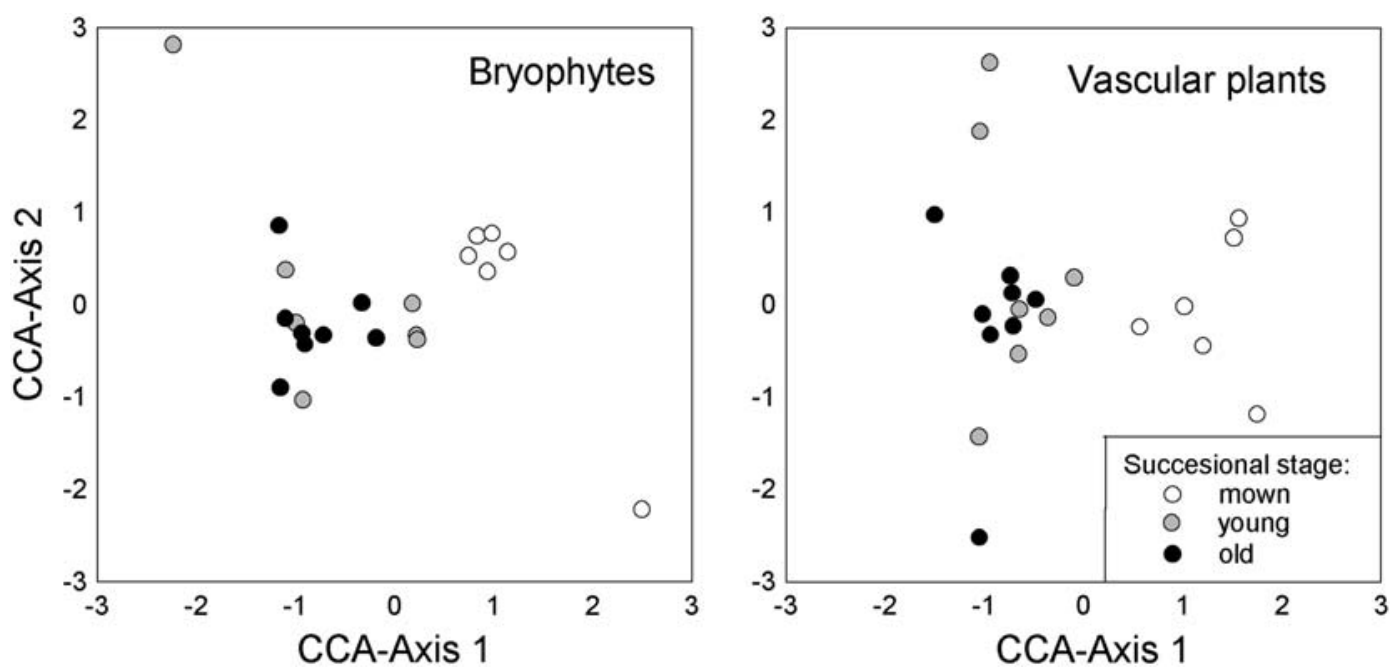

Figure 3. Ordination diagram for the canonical correspondence analysis of 21 sites (calcareous fens) of different successional stages based on frequency of species within sites.

(for a critical discussion, see Diemer et al. 2001). Although aboveground biomass in the studied fen meadows is limited (but not only) by nitrogen (Pauli et al. 2002), Diemer et al. (2001) found no significant relation between fallow age and total soil nitrogen and soil nitrate, respectively.

In contrast to vascular plant biomass, bryophyte biomass was lower in abandoned than in mown fens. By deposition of litter, the light environment, the water conditions and the soil temperature are markedly changed (Facelli and Pickett 1991). Of these changes, the lowered light levels may be the most important. Bryophyte growth is limited by light (Proctor 1981) and, thus, increased aboveground vascular plant biomass (Bergamini et al. 2001a) and litter cover (Hájková and Hájek 2003) are bound to reduce bryophyte biomass. For vascular plants, there is much evidence of toxic effects of litter leachates on germination and growth (Facelli and Pickett 1991). However, it is largely unknown whether such effects of litter on bryophyte growth exist. Furthermore, litter may also act as a mechanical barrier (Facelli and Pickett 1991) and inhibit the emergence of buried bryophyte shoots even if enough light is available.

\section{Species density}

Species density of bryophytes was $30 \%$ lower in abandoned than in mown fens. Reductions of species diversity were also found in one chalk grasslands after the cessation of management (van Tooren et al. 1990) but not in another (Vanderpoorten et al. 2003). Similar to bryophytes, species density of vascular plants was $32 \%$ lower in abandoned than mown fens. Diemer et al. (2001) who has investigated larger sampling plots $\left(2 \mathrm{~m}^{2}\right)$ observed a reduction of $18 \%$.

A part of the decrease of species density of both taxonomic groups can be explained by litter and aboveground biomass of vascular plants. For bryophytes, the two fitting sequences of the covariables showed that litter mass was more important, because the effect of litter mass was still significant when fitted after aboveground biomass of vascular plants, but the reverse was not true. As mentioned for bryophyte biomass, the reduced light levels and the mechanical impediments imposed by the litter layer are likely to be the main reasons for the decreased species density of bryophytes.

In contrast, the highly significant effects of litter mass and aboveground biomass of vascular plants on species density of vascular plants were rather independent of the fitting sequence. This indicates that, at least in part, both covariables contributed additively to the variation of species density. Litter accumulation is seen as an important factor influencing seed germination and establishment of seedlings (Facelli and Pickett 1991). This was also demonstrated for species of wet grasslands (Mass 
1988; Billeter and Diemer 2000; Jensen and Meyer 2001; Billeter et al. 2003). In their meta-analysis for several vegetation types, Xiong and Nilsson (1999) have found a significant correlation between litter mass and seedling establishment, but no such relation between litter and species richness. Nevertheless, it seems still probable that the decreased establishment of juvenile plants leads to a decrease of species richness. Evidently, since litter mass and vascular plant biomass are mostly positively correlated (Table 2), effects of these two variables are confounded. Only few experimental studies have separated the effects of litter and biomass (e.g., Nash Suding and Goldberg 1999; Xiong et al. 2003). Based on the results of a field experiment, Xiong et al. (2003) hypothesized, that the litter layer may act as filter, allowing only certain species to germinate and emerge, whereas canopy shade may discriminate less between species, but rather affect seedling numbers. Such an effect may explain the larger sum of squares of litter mass when fitted as the first covariable, in comparison when vascular plant biomass was fitted first (see Table 4).

Unexpectedly, species density of bryophytes was higher in old, rather than young successional stages of abandoned fens. This effect remained almost unchanged when the covariables 'litter mass' and 'vascular plant biomass' were fitted in the ANOVA models. One possible explanation is that habitat heterogeneity increased with fallow age, for example by tussock-building grasses and sedges, and led to an increase of spatial niches where shading by litter and vascular plant biomass was low. However, we found no species which had a significant indicator value for old successional fen meadows, but some species with high indicator values in mown fens, low values in young and again high values in old successional stages (e.g., Thuidium philibertii/delicatulum, Hylocomium splendens).

\section{Species composition}

The cessation of mowing also had a conspicuous effect on bryophyte and vascular plant species composition. Especially for vascular plants, this effect could be explained nearly equally well by litter biomass. For bryophytes, the effect of litter mass was far from significance $(p>0.1)$. Aston- ishingly, in our study $\mathrm{pH}$ was not significantly related to the species composition for both bryophytes and vascular plants. This contrasts with the findings of Bergamini et al. (2001b) who identified $\mathrm{pH}$ as the most important variable explaining bryophyte species composition of very similar communities in the same region. The cause for this discrepancy may be that the effects of region and $\mathrm{pH}$ were confounded. In fact, a separate CCA without the regions as covariables revealed that $\mathrm{pH}$ explained a significant amount of variation if it was the only variable included in the model (results not shown).

Interestingly, the effects of litter mass were dependent on the taxonomic group. While for vascular plants litter mass explained differences in species composition nearly equally well as abandonment, this was not the case for bryophytes. It is not clear why litter should not play an equally important role in structuring bryophyte communities. A thick persistent litter layer may also inhibit germination of bryophyte spores and/or prevent the establishment of new individuals since both process frequently depend on gaps created by disturbance (e. g. Jonsson 1993; Kimmerer and Young 1996). On the other hand, nutrientrich litter may also be important for the establishment of bryophytes by spores as was shown for peat mosses (Sundberg and Rydin 2002). Since size-variation within bryophytes is less than within vascular plants, most bryophytes will be affected in a similar way by litter, i.e. they will be buried. For vascular plants, however, burying by litter will only be a problem for the small species (e. g. Jensen and Meyer 2001). Thus, the litter layer may act as a strong filter for vascular plant species composition (cf. Xiong et al. 2003) but less so for bryophytes. The indicator analyses (Appendix Table A.1) showed that in particular small and short-lived vascular plants species diminished in abandoned fens. These species can be considered as weak competitors. For bryophytes there seems to be no relation of plant size and local extinction. Only two species were less abundant in abandoned fens and both are rather tall species of calcareous fens. Moreover, indicator species were exclusively found for mown fens signalling that there is no invasion of new species as it has been observed for vascular plants in other, more nutrient-rich wet grasslands (e.g., Jensen 1998). 


\section{Conclusions}

Traditionally, calcareous fen meadows were used as litter meadows and were mown every year in late summer. Without human activities wet forest communities will develop and eventually cover these sites. However, succession rate seems rather low and even oldest fallows ( $>30$ years) still contained a considerable number of characteristic fen species. Indicator analysis showed that there was no establishment of new species as it has been observed in other wet grasslands. Evidently, succession rate in nutrient-poor, montane fen meadows is lower than in lowlands where reed (Phragmites australis), tall sedges (Carex spp.), and even invasive species (Solidago gigantea) increased after abandonment (Voser-Huber 1992; Buchwald 1996; Brülisauer and Klötzli 1998).
Furthermore, the decrease of vascular plant species diversity in abandoned montane fens can be reversed after re-establishment of mowing (Güsewell et al. 1998; Billeter 2001). At least for bryophytes and vascular plants, re-introduction of mowing as a conservation measure may thus be promising, even in old fallows.

\section{Acknowledgements}

We thank Regula Billeter and Matthias Diemer for allowing us to use their field design and for improving a previous version of the manuscript, Oliver Schelske for help in the field and Karin Oetiker for providing her soil pH data. The study was financed partly by a grant of the Swiss National Science Foundation (Project 31-50669.97) to M. Diemer.

\section{Appendix}

Table A.1. Bryophyte and vascular plant species found in the studied fens and number of sites (No. sites) and plots (No. plots) in which they occurred.

\begin{tabular}{|c|c|c|c|c|c|c|c|}
\hline & No. sites & No. plots & CCA 1 & Mown & Young & Old & $p$ \\
\hline \multicolumn{8}{|l|}{ Bryophytes } \\
\hline Brachythecium rivulare & 1 & 1 & -1.126 & 0 & 0 & 13 & - \\
\hline Cratoneuron filicinum & 1 & 2 & -1.126 & 0 & 0 & 13 & - \\
\hline Bryum pseudotriquetrum & 2 & 3 & -1.080 & 0 & 0 & 25 & - \\
\hline Pellia spec. & 2 & 3 & -0.940 & 0 & 0 & 25 & - \\
\hline Barbilophozia barbata & 1 & 1 & -0.784 & 0 & 0 & 13 & - \\
\hline Sanionia uncinata & 1 & 1 & -0.784 & 0 & 0 & 13 & - \\
\hline Scapania aspera & 1 & 1 & -0.784 & 0 & 0 & 13 & - \\
\hline Tritomaria quinquedentata & 1 & 1 & -0.784 & 0 & 0 & 13 & - \\
\hline Plagiomnium undulatum & 2 & 3 & -0.779 & 0 & 29 & 0 & - \\
\hline Sphagnum angustifolium & 1 & 1 & -0.779 & 0 & 14 & 0 & - \\
\hline Sphagnum squarrosum & 1 & 1 & -0.779 & 0 & 14 & 0 & - \\
\hline Trichocolea tomentella & 1 & 1 & -0.779 & 0 & 14 & 0 & - \\
\hline Rhytidiadelphus subpinnatus & 2 & 2 & -0.761 & 0 & 8 & 6 & - \\
\hline Barbula gigantea & 1 & 1 & -0.743 & 0 & 14 & 0 & - \\
\hline Lophocolea bidentata & 4 & 8 & -0.726 & 0 & 15 & 12 & - \\
\hline Pleurozium schreberi & 4 & 7 & -0.719 & 0 & 17 & 10 & - \\
\hline Hylocomium pyrenaicum & 3 & 3 & -0.710 & 0 & 20 & 4 & - \\
\hline Cirriphyllum piliferum & 3 & 3 & -0.698 & 0 & 5 & 16 & - \\
\hline Lophozia cf. bantriensis & 3 & 4 & -0.621 & 0 & 4 & 18 & - \\
\hline Plagiochila asplenioides agg. & 7 & 10 & -0.581 & 2 & 6 & 33 & - \\
\hline Orthothecium rufescens & 1 & 1 & -0.566 & 0 & 14 & 0 & - \\
\hline Rhytidiadelphus spec. & 1 & 1 & -0.566 & 0 & 14 & 0 & - \\
\hline Cratoneuron decipiens & 2 & 5 & -0.484 & 4 & 0 & 9 & - \\
\hline Ctenidium molluscum & 13 & 31 & -0.293 & 18 & 19 & 25 & - \\
\hline Hylocomium splendens & 12 & 28 & -0.182 & 23 & 9 & 28 & - \\
\hline Campylium stellatum & 15 & 36 & -0.160 & 24 & 16 & 31 & - \\
\hline Rhytidiadelphus triquetrus & 7 & 10 & -0.155 & 18 & 3 & 17 & - \\
\hline Thuidium recognitum agg. & 16 & 31 & -0.070 & 38 & 11 & 32 & - \\
\hline
\end{tabular}


Table A.1. Continued.

\begin{tabular}{|c|c|c|c|c|c|c|c|}
\hline & No. sites & No. plots & CCA 1 & Mown & Young & Old & $p$ \\
\hline Calliergonella cuspidata & 18 & 49 & -0.002 & 44 & 21 & 24 & - \\
\hline Drepanocladus cossonii & 7 & 16 & 0.062 & 24 & 13 & 3 & - \\
\hline Fissidens adianthoides & 14 & 36 & 0.071 & 40 & 7 & 27 & - \\
\hline Plagiomnium affine agg. & 13 & 24 & 0.091 & 39 & 14 & 14 & - \\
\hline Cratoneuron falcatum & 7 & 11 & 0.123 & 25 & 15 & 2 & - \\
\hline Rhytidiadelphus squarrosus & 11 & 14 & 0.188 & 37 & 9 & 12 & - \\
\hline Scleropodium purum & 6 & 6 & 0.236 & 27 & 9 & 2 & - \\
\hline Tortella tortuosa & 2 & 2 & 0.282 & 10 & 0 & 5 & - \\
\hline Aulacomnium palustre & 6 & 17 & 0.340 & 29 & 6 & 2 & - \\
\hline Climacium dendroides & 12 & 25 & 0.581 & 69 & 8 & 5 & 0.002 \\
\hline Dicranum bonjeanii & 5 & 6 & 0.614 & 36 & 2 & 2 & - \\
\hline Brachythecium cf. glareosum & 4 & 6 & 0.995 & 43 & 2 & 0 & - \\
\hline Hypnum lindbergii & 3 & 8 & 1.078 & 50 & 0 & 0 & 0.012 \\
\hline Aneura pinguis & 1 & 1 & 1.313 & 17 & 0 & 0 & - \\
\hline Calliergon stramineum & 1 & 3 & 1.313 & 17 & 0 & 0 & - \\
\hline Scapania paludicola & 1 & 3 & 1.313 & 17 & 0 & 0 & - \\
\hline Sphagnum platyphyllum & 1 & 2 & 1.313 & 17 & 0 & 0 & - \\
\hline Sphagnum subsecundum & 1 & 1 & 1.313 & 17 & 0 & 0 & - \\
\hline Sphagnum warnstorfii & 1 & 3 & 1.313 & 17 & 0 & 0 & - \\
\hline Tomentypnum nitens & 1 & 1 & 1.313 & 17 & 0 & 0 & - \\
\hline Philonotis spec. & 1 & 1 & 1.525 & 17 & 0 & 0 & - \\
\hline \multicolumn{8}{|l|}{ Vascular plants } \\
\hline Abies alba & 1 & 1 & -1.186 & 0 & 0 & 13 & - \\
\hline Equisetum sylvaticum & 1 & 4 & -1.021 & 0 & 0 & 13 & - \\
\hline Viola biflora & 1 & 1 & -1.021 & 0 & 0 & 13 & - \\
\hline Calycocorsus stipitata & 3 & 4 & -0.845 & 0 & 0 & 38 & - \\
\hline Arnica montana & 1 & 1 & -0.839 & 0 & 0 & 13 & - \\
\hline Carex acutiformis & 1 & 1 & -0.839 & 0 & 14 & 0 & - \\
\hline Cirsium palustre & 1 & 1 & -0.839 & 0 & 14 & 0 & - \\
\hline Filipendula ulmaria & 1 & 1 & -0.839 & 0 & 14 & 0 & - \\
\hline Galium pumilum & 1 & 2 & -0.839 & 0 & 0 & 13 & - \\
\hline Homogyne alpina & 1 & 2 & -0.839 & 0 & 0 & 13 & - \\
\hline Agrostis tenuis & 8 & 10 & -0.772 & 0 & 19 & 35 & - \\
\hline Lysimachia nemorum & 3 & 7 & -0.757 & 0 & 43 & 0 & 0.043 \\
\hline Agrostis stolonifera & 1 & 1 & -0.724 & 0 & 14 & 0 & - \\
\hline Chaerophyllum hirsutum & 2 & 2 & -0.724 & 0 & 8 & 6 & - \\
\hline Deschampsia cespitosa & 1 & 1 & -0.724 & 0 & 14 & 0 & - \\
\hline Juncus inflexus & 1 & 1 & -0.724 & 0 & 14 & 0 & - \\
\hline Knautia dipsacifolia & 1 & 1 & -0.724 & 0 & 14 & 0 & - \\
\hline Phyteuma spicatum & 3 & 3 & -0.716 & 0 & 20 & 4 & - \\
\hline Vaccinium myrtillus & 3 & 3 & -0.716 & 0 & 20 & 4 & - \\
\hline Globularia nudicaulis & 2 & 2 & -0.713 & 0 & 8 & 6 & - \\
\hline Selaginella selaginoides & 5 & 6 & -0.706 & 0 & 23 & 12 & - \\
\hline Angelica sylvestris & 1 & 1 & -0.701 & 0 & 14 & 0 & - \\
\hline Equisetum telmateja & 1 & 1 & -0.701 & 0 & 0 & 13 & - \\
\hline Vaccinium vitis-idaea & 4 & 4 & -0.650 & 0 & 33 & 3 & - \\
\hline Calamagrostis varia & 2 & 3 & -0.587 & 0 & 29 & 0 & - \\
\hline Carex firma & 1 & 2 & -0.587 & 0 & 14 & 0 & - \\
\hline Carex montana & 1 & 1 & -0.587 & 0 & 14 & 0 & - \\
\hline Colchicum autumnale & 1 & 1 & -0.587 & 0 & 14 & 0 & - \\
\hline Erica carnea & 1 & 1 & -0.587 & 0 & 14 & 0 & - \\
\hline Gentiana clusii & 1 & 1 & -0.587 & 0 & 14 & 0 & - \\
\hline Picea abies & 1 & 1 & -0.587 & 0 & 0 & 13 & - \\
\hline Sesleria varia & 1 & 2 & -0.587 & 0 & 14 & 0 & - \\
\hline Trifolium montanum & 1 & 2 & -0.587 & 0 & 14 & 0 & - \\
\hline Carex flacca & 6 & 7 & -0.584 & 3 & 2 & 33 & - \\
\hline
\end{tabular}


Table A.1. Continued.

\begin{tabular}{|c|c|c|c|c|c|c|c|}
\hline & No. sites & No. plots & CCA 1 & Mown & Young & Old & $p$ \\
\hline Aster bellidiastrum & 15 & 31 & -0.498 & 7 & 17 & 56 & 0.012 \\
\hline Tofieldia calyculata & 5 & 6 & -0.416 & 3 & 10 & 11 & - \\
\hline Scabiosa columbaria & 3 & 3 & -0.369 & 7 & 0 & 15 & - \\
\hline Holcus lanatus & 3 & 4 & -0.346 & 5 & 0 & 17 & - \\
\hline Crepis paludosa & 9 & 16 & -0.327 & 15 & 19 & 10 & - \\
\hline Trollius europaeus & 9 & 13 & -0.324 & 9 & 13 & 21 & - \\
\hline Swertia perennis & 9 & 16 & -0.291 & 11 & 11 & 19 & - \\
\hline Carex ferruginea & 13 & 29 & -0.271 & 14 & 14 & 35 & - \\
\hline Caltha palustris & 3 & 4 & -0.238 & 5 & 7 & 3 & - \\
\hline Parnassia palustris & 13 & 16 & -0.233 & 20 & 15 & 28 & - \\
\hline Primula farinosa & 11 & 15 & -0.229 & 16 & 14 & 22 & - \\
\hline Succisa pratensis & 15 & 42 & -0.227 & 14 & 47 & 16 & - \\
\hline Molinia caerulea & 21 & 81 & -0.200 & 33 & 33 & 34 & - \\
\hline Potentilla erecta & 21 & 67 & -0.196 & 33 & 31 & 35 & - \\
\hline Trichophorum cespitosum & 11 & 25 & -0.194 & 16 & 16 & 19 & - \\
\hline Carex pallescens & 3 & 4 & -0.192 & 5 & 7 & 3 & - \\
\hline Dactylorhiza maculata & 6 & 7 & -0.169 & 6 & 8 & 14 & - \\
\hline Acer pseudoplatanus & 3 & 3 & -0.169 & 6 & 18 & 0 & - \\
\hline Prunella grandiflora & 2 & 2 & -0.134 & 39 & 4 & 17 & - \\
\hline Valeriana dioica & 10 & 13 & -0.125 & 18 & 26 & 7 & - \\
\hline Equisetum palustre & 18 & 37 & -0.121 & 37 & 28 & 23 & - \\
\hline Carex davalliana & 19 & 54 & -0.103 & 32 & 33 & 25 & - \\
\hline Sanguisorba officinalis & 3 & 4 & -0.095 & 5 & 4 & 6 & - \\
\hline Galium uliginosum & 6 & 13 & -0.055 & 23 & 1 & 12 & - \\
\hline Bartsia alpina & 9 & 13 & -0.049 & 18 & 16 & 10 & - \\
\hline Ranunculus aconitifolius & 3 & 3 & -0.015 & 6 & 5 & 4 & - \\
\hline Ranunculus nemorosus agg. & 2 & 3 & -0.015 & 6 & 9 & 0 & - \\
\hline Soldanella alpina & 8 & 10 & 0.017 & 23 & 6 & 13 & - \\
\hline Polygala vulgaris & 3 & 3 & 0.031 & 13 & 0 & 3 & - \\
\hline Pinguicula alpina/vulgaris & 3 & 3 & 0.031 & 6 & 5 & 4 & - \\
\hline Chrysanthemum leucanthemum agg. & 6 & 7 & 0.095 & 16 & 2 & 14 & - \\
\hline Carex panicea & 17 & 44 & 0.099 & 49 & 17 & 20 & 0.037 \\
\hline Hippocrepis comosa & 2 & 3 & 0.115 & 6 & 9 & 0 & - \\
\hline Gymnadenia conopsea & 3 & 4 & 0.137 & 9 & 3 & 3 & - \\
\hline Cirsium rivulare & 4 & 5 & 0.154 & 8 & 3 & 9 & - \\
\hline Leontodon hispidus & 12 & 29 & 0.159 & 42 & 5 & 20 & - \\
\hline Hieracium murorum agg. & 2 & 2 & 0.180 & 9 & 7 & 0 & - \\
\hline Calluna vulgaris & 2 & 2 & 0.248 & 9 & 7 & 0 & - \\
\hline Carex flava agg. & 2 & 2 & 0.248 & 10 & 0 & 5 & - \\
\hline Lotus corniculatus & 10 & 12 & 0.269 & 46 & 10 & 5 & - \\
\hline Polygonum bistorta & 2 & 2 & 0.271 & 6 & 5 & 4 & - \\
\hline Stachys officinalis & 2 & 2 & 0.271 & 9 & 7 & 0 & - \\
\hline Thymus pulegioides & 2 & 2 & 0.271 & 10 & 0 & 5 & - \\
\hline Cardamine pratensis agg. & 4 & 4 & 0.300 & 18 & 3 & 3 & - \\
\hline Epipactis palustris & 6 & 7 & 0.304 & 31 & 8 & 1 & - \\
\hline Prunella vulgaris & 11 & 21 & 0.309 & 10 & 0 & 5 & - \\
\hline Carex nigra & 9 & 13 & 0.340 & 39 & 12 & 3 & - \\
\hline Primula elatior & 5 & 6 & 0.343 & 18 & 20 & 0 & - \\
\hline Ranunculus montanus & 15 & 33 & 0.360 & 60 & 11 & 13 & 0.005 \\
\hline Eriophorum latifolium & 11 & 13 & 0.364 & 49 & 16 & 3 & - \\
\hline Carex pulicaris & 9 & 16 & 0.372 & 53 & 0 & 18 & 0.020 \\
\hline Briza media & 10 & 18 & 0.386 & 40 & 15 & 3 & - \\
\hline Carex echinata & 7 & 9 & 0.389 & 30 & 6 & 5 & - \\
\hline Polygonum viviparum & 2 & 4 & 0.392 & 9 & 7 & 0 & - \\
\hline Juncus alpinus & 8 & 13 & 0.408 & 56 & 2 & 5 & 0.019 \\
\hline Centaurea jacea & 6 & 10 & 0.411 & 43 & 4 & 1 & - \\
\hline
\end{tabular}


Table A.1. Continued.

\begin{tabular}{|c|c|c|c|c|c|c|c|}
\hline & No. sites & No. plots & CCA 1 & Mown & Young & Old & $p$ \\
\hline Festuca rubra & 8 & 11 & 0.434 & 39 & 14 & 1 & - \\
\hline Anthoxanthum odoratum & 6 & 8 & 0.597 & 33 & 15 & 0 & - \\
\hline Gentiana asclepiadea & 3 & 4 & 0.629 & 27 & 0 & 3 & - \\
\hline Lathyrus pratensis & 4 & 4 & 0.699 & 40 & 0 & 3 & - \\
\hline Carex hostiana & 4 & 5 & 0.757 & 41 & 3 & 0 & - \\
\hline Gentiana verna & 3 & 4 & 0.763 & 27 & 0 & 3 & - \\
\hline Linum catharticum & 7 & 12 & 0.847 & 52 & 4 & 1 & 0.021 \\
\hline Phyteuma cf. orbiculare & 1 & 2 & 0.918 & 17 & 0 & 0 & - \\
\hline Plantago lanceolata & 5 & 11 & 1.168 & 61 & 1 & 0 & 0.011 \\
\hline Trifolium pratense & 7 & 13 & 1.176 & 93 & 1 & 0 & 0.001 \\
\hline Polygala amarella & 4 & 6 & 1.208 & 67 & 0 & 0 & 0.002 \\
\hline Eriophorum angustifolium & 1 & 2 & 1.266 & 17 & 0 & 0 & - \\
\hline Euphrasia rostkoviana & 3 & 6 & 1.285 & 50 & 0 & 0 & 0.014 \\
\hline Cynosurus cristatus & 1 & 1 & 1.381 & 17 & 0 & 0 & - \\
\hline Hieracium umbellatum & 1 & 1 & 1.381 & 17 & 0 & 0 & - \\
\hline Lotus pedunculatus & 1 & 1 & 1.381 & 17 & 0 & 0 & - \\
\hline Rhinanthus alectorolophus & 2 & 2 & 1.392 & 33 & 0 & 0 & - \\
\hline Hieracium lactucella & 1 & 1 & 1.403 & 17 & 0 & 0 & - \\
\hline Ajuga reptans & 1 & 1 & 1.518 & 17 & 0 & 0 & - \\
\hline Campanula scheuchzeri & 1 & 1 & 1.518 & 17 & 0 & 0 & - \\
\hline Juncus effusus & 1 & 1 & 1.518 & 17 & 0 & 0 & - \\
\hline
\end{tabular}

Species are sorted in ascending order according to their CCA-score on the first axis. Low scores denote species found in abandoned fens, high scores species in mown fens. Indicator values after Dufrêne and Legendre (1997) are given separately for mown, young and old successional fens meadows; $p$-values refer to the highest of the three values for each species and are printed if $p<0.05$. Plagiomnium affine agg. includes $P$. affine s.str., P. elatum, P. ellipticum and P. medium. Thuidium recognitum agg. includes $T$. recognitum, T. philibertii and $T$. delicatulum s. str. Plagiochila asplenioides agg. includes $P$. asplenioides s.str., P. porellioides and $P$. britannica.

\section{References}

Bates J.W. 1988. The effects of shoot spacing on the growth and branch development of the moss Rhytidiadelphus triquetrus. New Phytol. 109: 499-504.

Bergamini A. and Pauli D. 2001. Effects of increased nutrient supply on bryophytes in montane calcareous fens. J. Bryol. 23: $331-339$.

Bergamini A., Pauli D., Peintinger M. and Schmid B. 2001a. Relationships between productivity, number of shoots and number of species in bryophytes and vascular plants. J. Ecol. 89: 920-929.

Bergamini A., Peintinger M., Schmid B. and Urmi E. $2001 \mathrm{~b}$. Effects of management and altitude on bryophyte species diversity and composition in montane calcareous fens. Flora 196: $180-193$.

Bergamini A. and Peintinger M. 2002. Effects of light and nitrogen on morphological plasticity of the moss Calliergonella cuspidata. Oikos 96: 355-363.

Billeter R. 2001. Secondary succession in fens - from communities to genes. Dissertation, University of Zürich, Zürich.

Billeter R. and Diemer M. 2000. Effects of abandonment on Tofieldia calyculata (Liliaceae), a common, subdominant wetland species. Bull. Geobot. Inst. ETH 66: 37-46.

Billeter R., Hooftman D. and Diemer M. 2003. Differential and reversible responses of common fen meadow species to abandonment. Appl. Veget. Sci. 6: 3-12.
Bosshard A., Andres F., Stromeyer S. and Wohlgemuth T. 1988. Wirkung einer kurzfristigen Brache auf das Ökosystem eines anthropogenen Kleinseggenriedes. Berichte Geobot. Inst. ETH, Stiftung Rübel, Zürich 54: 181-220.

Brülisauer A. and Klötzli F. 1998. Habitat factors related to the invasion of reeds (Phragmites australis) into wet meadows of the Swiss Midlands. Zeits. Ökol. Nat. 7: $125-136$.

Buch H. 1947. Über die Wasser- und Mineralnährstoffversorgung der Moose I, II. Soc. Sci. Fenn. Comment. Biol. 9(16): $1-44,9(20): 1-49$.

Buchwald R. 1996. Basikline Pfeifengraswiesen (Molinietum caeruleae) und ihre Kontaktvegetation im weiteren AlbWutach-Gebiet (Hochrhein, SW-Deutschland). I. Verbreitung, Synsystematik und Verbrachung der Pfeifengraswiesen. Tuexenia 16: 179-225.

BUWAL 1990. Inventar der Flachmoore von nationaler Bedeutung. Entwurf zur Vernehmlassung. Bundesamt für Umwelt, Wald und Landschaft (BUWAL), Bern.

Diemer M., Oetiker K. and Billeter R. 2001. Abandonment alters community composition and canopy structure of Swiss calcareous fens. Appl. Veget. Sci. 4: 237-246.

Dufrêne M. and Legendre P. 1997. Species assemblages and indicator species: the need for a flexible asymmetrical approach. Ecol. Monogr. 67: 345-366.

Ellenberg H. 1996. Vegetation Mitteleuropas mit den Alpen in ökologischer, dynamischer und historischer Sicht. Ulmer, Stuttgart. 
Facelli J.M. and Pickett S.T.A. 1991. Plant litter: its dynamics and effects in plant community structure. Bot. Rev. 57: 1 32.

Frego K.A. and Carleton T.J. 1995. Microsite tolerance of four bryophytes in a mature black spruce stand: reciprocal transplants. The Bryologist 98: 452-458.

Geissler P., Urmi E. and Schnyder N. 1998. Liste der Moose der Schweiz und ihrer Grenzgebiete. In: Schneider H. and Paulsen J. (eds.). CD Schweizer Botanik '98, Basel.

Güsewell S., Buttler A. and Klötzli F. 1998. Short and longterm effects of mowing on the vegetation of two calcareous fens. J. Veget. Sci. 9: 861-872.

Hájková P. and Hájek M. 2003. Species richness and aboveground biomass of poor and calcareous spring fens in the flysch West Carpathians, and their relationships to water and soil chemistry. Preslia 75: 271-287.

Ingerpuu N., Vellak K., Kukk T. and Pärtel M. 2001. Bryophyte and vascular plant species richness in boreo-nemoral moist forest and mires. Biodivers. Conserv. 10: 2153-2166.

Jensen K. 1998. Species composition of soil seed bank and seed rain of abandoned wet meadows and their relation to aboveground vegetation. Flora 193: 345-359.

Jensen K. and Meyer C. 2001. Effects of light competition and litter on the performance of Viola palustris and on species composition and diversity of an abandoned fen meadow. Plant Ecol. 155: 169-181.

Jensen K. and Schrautzer J. 1999. Consequences of abandonment for a regional fen flora and mechanisms of succesional stages. Appl. Veget. Sci. 2: 79-88.

Jonsson B.G. 1993. The bryophyte diaspore bank and its role after small-scale disturbance in a boreal forest. J. Veget. Sci. 4: 819-826.

Kimmerer R.W. and Young C.C. 1996. Effect of gap size and regeneration niche on species coexistence in bryophyte communities. Bull. Torrey Bot. Club 123: 16-24.

Klimeš L., Dančak M., Hájek M., Jongepierová I. and Kučera T. 2001. Scale-dependent biases in species counts in grassland. J. Veget. Sci. 12: 699-704.

Lauber K. and Wagner G. 1996. Flora Helvetica. Paul Haupt, Bern.

Maas D. 1988. Keimung und Etablierung von Streuwiesenpflanzen nach experimenteller Ansaat. Nat. Landschaft 63: $411-415$

McCullagh P. and Nelder J.A. 1983. Generalized Linear Models. Chapman and Hall, London.

McCune B. and Mefford J.M. 1997. PC-ORD. Multivariable Analysis of Ecological Data Version 3.0. MjM Software Design, Gleneden Beach (Oregon).

Nash Suding K. and Goldberg D.E. 1999. Variation in the effects of vegetation and litter on recruitment across productivity gradients. J. Ecol. 87: 436-449.

Økland R.H. 2000. Population biology of the clonal moss Hylocomium splendens in Norwegian boreal spruce forests. 5. Vertical dynamics of individual shoot segments. Oikos 88 : 449-469.

Pauli D., Peintinger M. and Schmid B. 2002. Nutrient enrichment in calcareous fens: effects on plant species and community structure. Basic Appl. Ecol. 3: 255-266.

Payne R.W., Lane P.V., Digby P.G.N., Harding S.A., Leech P.K., Morgan G.W., Todd A.D., Thompson R., Tunnicliffe Wilson G., Welham S.J. and White R.P. 1993. GENSTAT 5
Release 3. Reference Manual. Oxford University Press, Oxford.

Peintinger M., Bergamini A. and Schmid B. 2003. Species-area relationships and nestedness of four taxonomic groups in fragmented wetlands. Basic Appl. Ecol. 4: 385-394.

Proctor M.C.F. 1981. Physiological ecology of bryophytes. Adv. Bryol. 1: 79-166.

Rincon E. 1988. The effects of herbaceous litter on bryophyte growth. J. Bryol. 15: 209-217.

Rincon E. and Grime J.P. 1989. Plasticity and light interception by six bryophytes of contrasted ecology. J. Ecol. 77: 439-446.

Rosenthal R. and Rosnow R.L. 1985. Contrast Analysis: Focused Comparisons in the Analysis of Variance. Cambridge University Press, Cambridge.

Rydin H. 1997. Competition among bryophytes. Adv. Bryol. 6: $135-168$.

Ryser P., Langenauer R. and Gigon A. 1995. Species richness and vegetation structure in a limestone grassland after 15 years management with six biomass removal regimes. Folia Geobot. Phytotaxon. 30: 157-167.

Schiefer J. 1981. Bracheversuche in Baden-Württemberg. Beihefte zu den Veröffentlichungen für Naturschutz und Landschaftspflege in Baden-Württemberg 22: 1-325.

Stöcklin J. and Gisi U. 1989. Auswirkungen der Brachlegung von Mähwiesen auf die Produktion pflanzlicher Biomasse und die Menge und Struktur der Streudecke. Acta Oecol. Oecol. Appl. 10: 259-270.

Sundberg S. and Rydin H. 2002. Habitat requirements for establishment of Sphagnum from spores. J. Ecol. 90: $268-278$.

ter Braak C.F.J. 1986. Canonical correspondence analysis: a new eigenvector technique for multivariable direct gradient analysis. Ecology 67: 1167-1179.

ter Braak C.F.J. and Smilauer P. 1998. CANOCO Reference Manual and User's Guide to CANOCO for Windows. Software for Canonical Community Ordination (version 4). Centre for Biometry, Wageningen.

Uttinger H. 1967. Klima und Wetter II. In: Imhof E. (ed.), Atlas der Schweiz, Tafel 12. Eidgenössische Landestopographie, Bern-Wabern (Switzerland).

Vanderpoorten A., Delescaille L.-M. and Jacquemart A.-L. 2003. The bryophyte layer in a calcareous grassland after a decade of contrasting mowing regimes. Biol. Conserv. 117: $11-18$.

von Tooren B.F., van Dam D. and During H.J. 1988. Effects of simulated shade on growth, morphology and competitive interactions in two pleurocarpous mosses. J. Bryol. 20: $301-310$.

von Tooren B.F., Odé B., During H.J. and Bobbink R. 1990. Regeneration of species richness in the bryophyte layer of Dutch chalk grasslands. Lindbergia 16: 153-160.

Voser-Huber M.-L. 1992. Goldruten - Probleme in Naturschutzgebieten. Schriftenreihe Umwelt 167 (Bundesamt für Umwelt, Wald und Landschaft): 1-22.

Wheeler B.D. and Giller K.E. 1982. Species richness of herbaceous fen vegetation in Broadland, Norfolk, in relation to the quantity of above-ground plant material. J. Ecol. 70: $179-200$.

Xiong S. and Nilsson C. 1999. The effects of plant litter on vegetation: a meta-analysis. J. Ecol. 87: 984-994. 
Xiong S., Johansson M.E., Hughes F.M.R., Hayes A., Richards K.S. and Nilsson C. 2003. Interactive effects of soil moisture, vegetation canopy, plant litter and seed addition on plant diversity in a wetland community. J. Ecol. 91: 976-986.
Zoller H. and Bischof N. 1980. Stufen der Kulturintensität und ihr Einfluss auf Artenzahl und Artengefüge der Vegetation. Phytocoenologia 7: 35-51. 